\title{
Developing bilingual learning multimedia in integral application learning material for vocational school
}

\author{
Abdul Rahim', Syukrul Hamdi', I Nyoman Arcana ${ }^{3}$ \\ ${ }^{1}$ Department of Education Research and Evaluation, Yogyakarta State University, Indonesia \\ ${ }^{2}$ Department of Mathematics Education, Yogyakarta State University, Indonesia \\ ${ }^{3}$ Department of Mathematics Education, Sarjanawiyata Tamansiswa University, Indonesia \\ $\llbracket$ abdulrahim.2019@student.uny.ac.id
}

Article Information

Submitted July 05, 2020

Revised August 05, 2020

Accepted September 10, 2020

Keywords

Bilingual; Integral Application; Multimedia.

\section{Abstract}

ICT advancement can be utilized to improve the quality of education. In this globalization era, the millennial generation is demanded to be technology literate and fluent in English to compete in the global world considering that English has been established as an international language. Therefore, the integration of English into learning in the form of multimedia bilingual learning is needed. This study aimed to determine the feasibility, attractiveness, and effectiveness of bilingual learning multimedia on the integral application material for vocational schools. This research is research and development. Based on the results of validation and field trials, the developed bilingual mathematics learning media was in the feasible, interesting, and effective categories. The feasibility of the bilingual learning multimedia based on the material expert validation obtained an average of 4.6 and the media expert validation obtained an average of 4.9 which indicated that the developed product was in the feasible category. The attractiveness of bilingual mathematics learning multimedia based on students' responses was $89 \%$ in the very interesting category. The effectiveness of the developed bilingual learning multimedia to improve students' mathematics learning outcomes was known based on the N-Gain value of 0.8 in the high category.

\section{INTRODUCTION}

Mathematics is one of the important lessons in the development of science. Mathematics has more study hours compared to other subjects. It is also a science that plays an important role in life and is a useful branch of science for engaging and socializing in society (Purwanti et al., 2016, p. 1; Sholihah \& Mahmudi, 2015, p. 176; Ulpah \& Novikasari, 2020, p. 30). The Program for International Students Assessment (PISA) reported that Indonesia was ranked 72 out of 78 countries in mathematics with a score of 379 (OECD, 2018, p. 3). At present, students' mathematic learning interest is lacking caused by a lot of mathematical, logical, and systematic formula. It is also characterized by its abstract and difficult to solve characteristics (Mukhni et al., 2020, p. 1; Widyastuti et al., 2018, p. 84; Zengin, 2017, p. 95). Most students consider mathematics as a difficult and annoying subject, even becoming an obstacle to their studies. This negative impression of mathematics will negatively affect their motivation to learn mathematics (Syamarro et al., 2015, p. 106).

Education is currently facing challenges from the outside world such as competence, public perception, pedagogic knowledge, development, as well as phenomena that will occur in the future, such as challenges in using English. Although International Pilot Schools (RSBI) and International Standard Schools (SBI) are gone, learning to use English (bilingual) must be anticipated because it is one of the promising strategies to face global competition and also 
English is a universal language that has been recognized by all countries. Even more, Indonesia is participating in the ASEAN Economic Community (AEC) where the program is more focused on economic, social, culture, and education. Also, there will be student exchange programs and the transfer of new students from other countries.

The rapid development of technology in the current era of globalization has also affected the world of education. An adjustment in the world of education with technological advancements can be done through the use of information and communication technology to improve the quality of education, especially in the learning process (Gündüz, 2010, p. 45; Leow \& Neo, 2014, p. 99; Made Rajendra \& Made Sudana, 2018, p. 1; Muchlas, 2018, p. 62; Neo et al., 2008, p. 659; Rusman et al., 2011, p. 1; Sarac, 2017, p. 306). Educational technology can be applied through learning media. The use of instructional media has a positive impact on the teaching and learning process so that it helps to clarify learning materials to be more effective, dynamic, and not monotonous (Triyanto et al., 2013, p. 236). Through learning media, teachers can create a variety of classroom situations and determine learning methods that will be used in a different environment which is fun, interesting, always thinking creatively and excitedly, and increasing students' interest in learning (Merliana et al., 2019, p. 224). The learning media that can be developed for mathematics learning is Adobe Flash.

Adobe Flash, formerly known as Macromedia Flash, is an application that allows programmers to create content to be displayed online. Flash uses vector graphics and a combination of programming languages called action script and is most often used to create high-impact moving images to create websites that attract attention (Reimers \& Stewart, 2007, p. 365). Some previous developmental research had been conducted that used Adobe Flash to produce learning media that are feasible, interesting, and effective in the development of mathematics student worksheet on fraction material, the development of mathematics learning media on geometry material, the development of digital learning media mathematics modules on relations and functions material, the development of mathematics learning media on prism and pyramid material, and the development of mathematics learning media on geometry and measurement material (Fadila et al., 2019; Nelwati et al., 2019; Setiyani et al., 2020; Susilawati et al., 2018; Zainil et al., 2018).

Based on previous research, this research developed a novel learning media in the form of bilingual mathematics learning multimedia on integral application material using Adobe Flash software by combining text; buttons that function to connect slides when displaying media, images, animations; Indonesian-English dictionaries, pronunciation, music, and videos. The development was done to produce interesting, motivating, and interesting learning media. In the development of the learning media, simulations were given to stimulate students' way of thinking. The research and development had been carried out to determine the feasibility, attractiveness, and effectiveness of bilingual mathematics learning multimedia in the integral application material.

\section{METHODS}

This research was conducted using the Research \& Development (R\&D) method. The development procedure followed the modified Borg \& Gall procedure consisted of seven stages instead of ten. The simplification and limitation of the ten stages to seven stages were due to limited energy, funds, and time (Sugiyono, 2013, p. 118). The sampling technique used was the purposive sampling technique. The field-trial subjects of this research were 50 students of 
Muhammadiyah Prambanan Vocational School. The data collection instruments used were validation sheets, questionnaires, and tests. Data analysis techniques used in research and development was the descriptive quantitative to process the data in the form of scores based on the validators' assessments, the descriptive percentage to process data in the form of scores based on the subjects' responses, and the descriptive qualitative to describe the data in the form of comments and suggestions from the validators. To find out the effectiveness of the developed media, the N-Gain formula was used. The feasibility and attractiveness assessment techniques for data analysis were Likert scales with the rating scales of 1-5. The steps referred to are presented in Figure 1 (Kesumayanti \& Putra, 2017, p. 130; Wahyuni et al., 2019, p. 34).

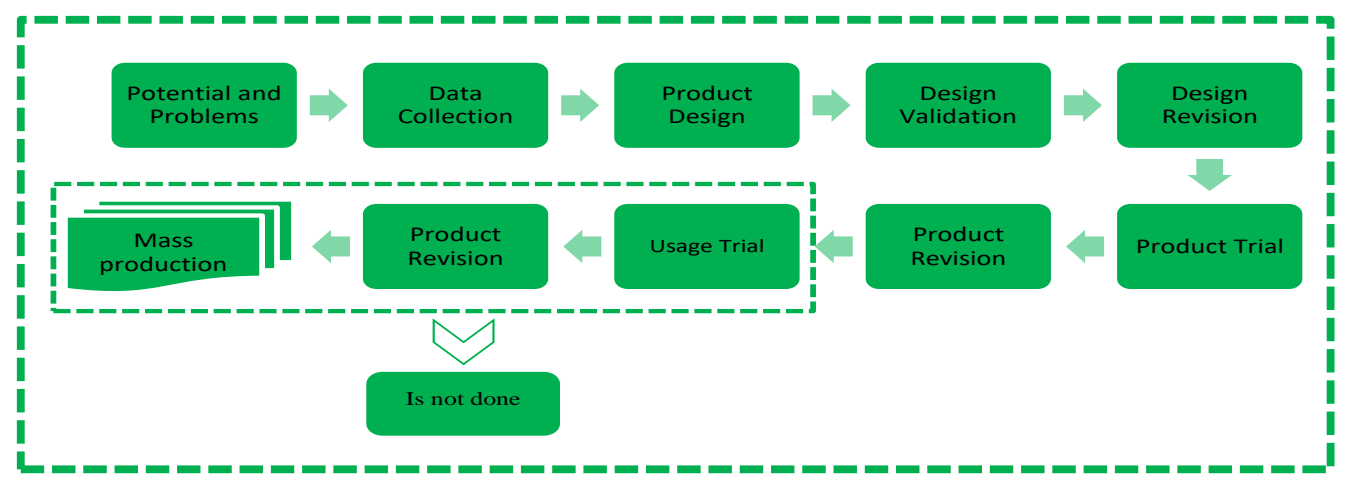

Figure 1. The Stages of Research Development

The validation by material and media experts for the feasibility of the developed multimedia obtained quantitative data which was then analyzed by descriptive statistics. The reference for changing the scores to a scale of five is presented in Table 1. (Hardiyantari, 2017, p. 79; Saputri et al., 2020, p. 95; Sari \& Wati, 2020, p. 4).

Table 1. Assessment Criteria

\begin{tabular}{cccc}
\hline \multirow{2}{*}{ Score } & Score & Feasibility \\
\cline { 2 - 3 } & $X>X_{i}+1,8 S B_{i}$ & Calculation & \begin{tabular}{c} 
Criteria \\
\hline 5
\end{tabular}$X_{i}+0,6 S B_{i}<X \leq X_{i}+1,8 S D$ \\
4 & $X_{i}-0,6 S B_{i}<X \leq X_{i}+0,6 S B_{i}$ & $3,40<X \leq 4,20$ & Excellent \\
3 & $X_{i}-1,8 S B_{i}<X \leq X_{i}-0,6 S B_{i}$ & $2,60<X \leq 3,40$ & Hoderate \\
2 & $X \leq X_{i}-1,8 S B_{i}$ & $1,80<X \leq 2,60$ & Low \\
1 & & $X \leq 1,80$ & Poor \\
\hline
\end{tabular}

\section{Description:}

$\mathrm{X}=$ Respondent's score

$\mathrm{X}_{\mathrm{i}} \quad=$ Mean ideal, 1/2 (ideal maximum score + ideal minimum score)

$\mathrm{SB}_{\mathrm{i}} \quad=$ Ideal standard deviation, 1/6 (ideal maximum score - ideal minimum score)

Ideal maximum score $=\Sigma$ item criteria $\times$ high score

Ideal minimum score $=\Sigma$ item criteria $\times$ lowest score

The students' responses on the questionnaire regarding the attractiveness of the multimedia were analyzed to determine the percentage of overall respondents' answers with the following formula : (Diani et al., 2018, p. 236; Otoluwa et al., 2020, p. 3; Rizki et al., 2020, p. 81; Setyowati \& Mintohari, 2020, p. 104)

$$
P=\frac{\sum x}{\sum x_{i}} \times 100 \%
$$


Description:

P: Percentage

$\sum \mathrm{x}$ : Number of respondents' answers in one item

$\sum \mathrm{x}_{\mathrm{i}}$ : The ideal score of an item

Then, the percentage of attractiveness criteria was determined using the criteria in table 2 .

Table 2. Criteria for the Interpretation of Attractiveness

\begin{tabular}{cc}
\hline Interval & Criteria \\
\hline $0 \%-20 \%$ & Very unattractive \\
$21 \%-40 \%$ & Unattractive \\
$41 \%-60 \%$ & Quite attractive \\
$61 \%-80 \%$ & Attractive \\
$81 \%-100 \%$ & Very attractive \\
\hline
\end{tabular}

To determine the effectiveness of the developed media, the results of the pretest and posttest obtained during the field trial were compared. The improvement of understanding before and after learning had been calculated using the $\mathrm{N}$-gain formula. The $\mathrm{N}$-gain formula is as follows: (Hake, 1998, p. 65; Mabruri et al., 2019, p. 111).

$$
N-\text { gain }=\frac{S_{\text {post }}-S_{\text {pre }}}{S_{\max }-S_{\text {pre }}}
$$

Description:

$S_{\text {post: }}$ Posttest score

$\mathrm{S}_{\mathrm{pre}}$ : Pretest score

$\mathrm{S}_{\max }$ : Maximum Score

The obtained value was then interpreted using the gain value classification in Table 3 (Hake, 1998, p. 65; Supandi \& Senam, 2020, p. 167).

Table 3. Gain Value Classification

\begin{tabular}{cc}
\hline Score & Classification \\
\hline$N-$ gain $\geq 0,7$ & High \\
$0,7>N-$ gain $\geq 0,3$ & Moderate \\
$N-$ gain $<0,3$ & Low \\
\hline
\end{tabular}

\section{RESULTS AND DISCUSSION}

Based on the bilingual learning models, experts identify bilingual programs into three types, namely transitional, maintenance, and enrichment (Margana \& Sukarno, 2011, p. 82). With the help of information and communication technology, the developed product can be used in all three bilingual learning models.

The result of this research was learning multimedia in the integral application material. The development procedures consisted of seven stages. The first stage was the potential and problems. At this stage, exploration had been done to obtain more knowledge about matters related to the development of the product. The exploration covered the curriculum, core competencies (KI), basic competencies (KD), indicators, subject matter, students' 
characteristics, the situation of the school, and product specifications and components. All of these exploration results were used as ingredients to develop the product.

The second stage was data collection. The researchers collected information that supported the development the learning multimedia. The references used were mathematics books for the twelfth-grade students of high school/vocational school by Yudhistira entitled Mathematics for Senior High School Year XII and mathematics book for high school by Sartono Wirodikromo entitled Mathematics for Class XII High School.

The third stage was the product design. The product was developed based on the results of the analysis of the potential and problems. The activities done at this stage were preparing the integral application materials and their completeness (test questions, answers, etc.), dubbing, making or collecting learning videos, making animations, and making software/multimedia programs (products). The multimedia components consisted of an opening menu, help menu, KI/KD menu, material menu, video menu, evaluation menu, profile menu, and exit menu.

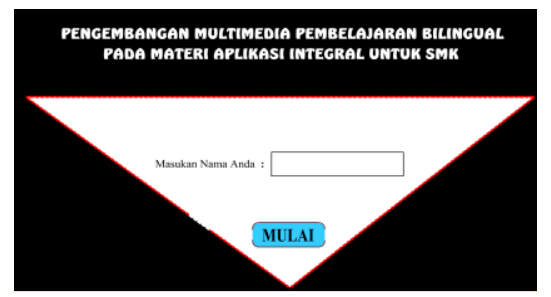

Figure 2. Opening Menu

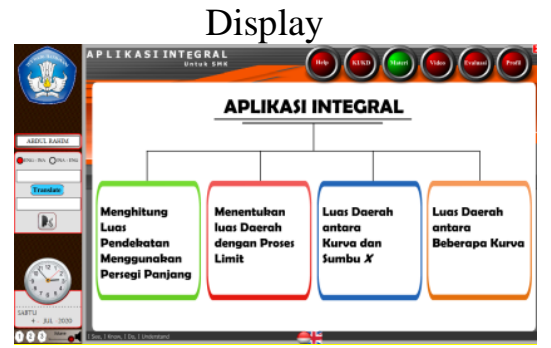

Figure 5. Material Menu in

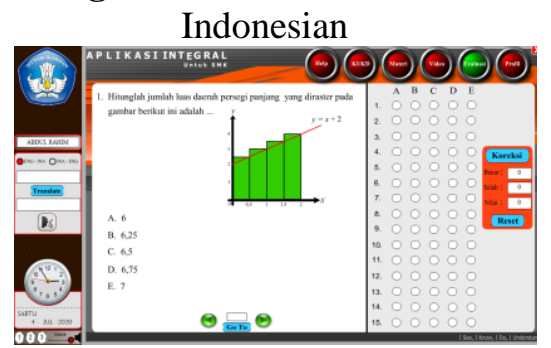

Figure 8. Evaluation of Menu Display

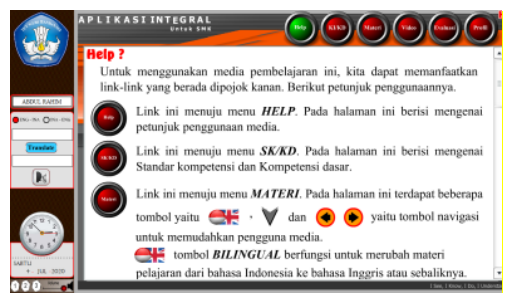

Figure 3. Help Menu Display

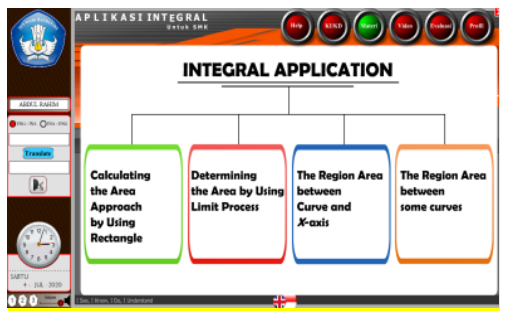

Figure 6. Material Menu in English

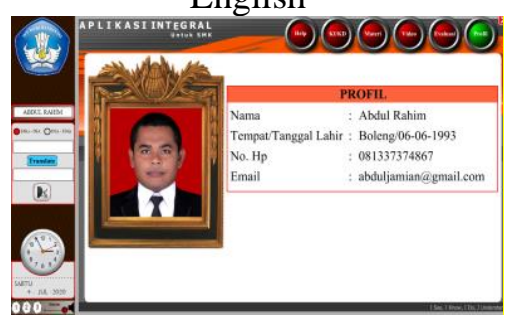

Figure 9. Profile Menu Display

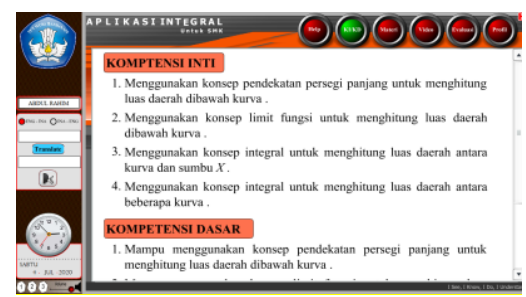

Figure 4. KI / SD Display Menu

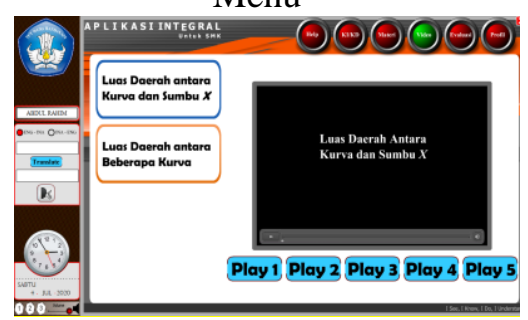

Figure 7. Video Display Menu

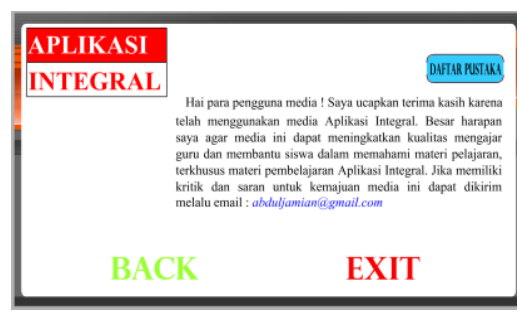

Figure 10. Exit Menu Display

The fourth stage was the design validation. The developed media had been validated by material experts and media experts to determine the feasibility as well as to obtain guidelines for product revision. The validation by material experts on the aspects of content worthiness; recency, accuracy, feasibility; and grammar obtained an average of 4.6 within the highly feasible category. The following is the result of material expert validation: 


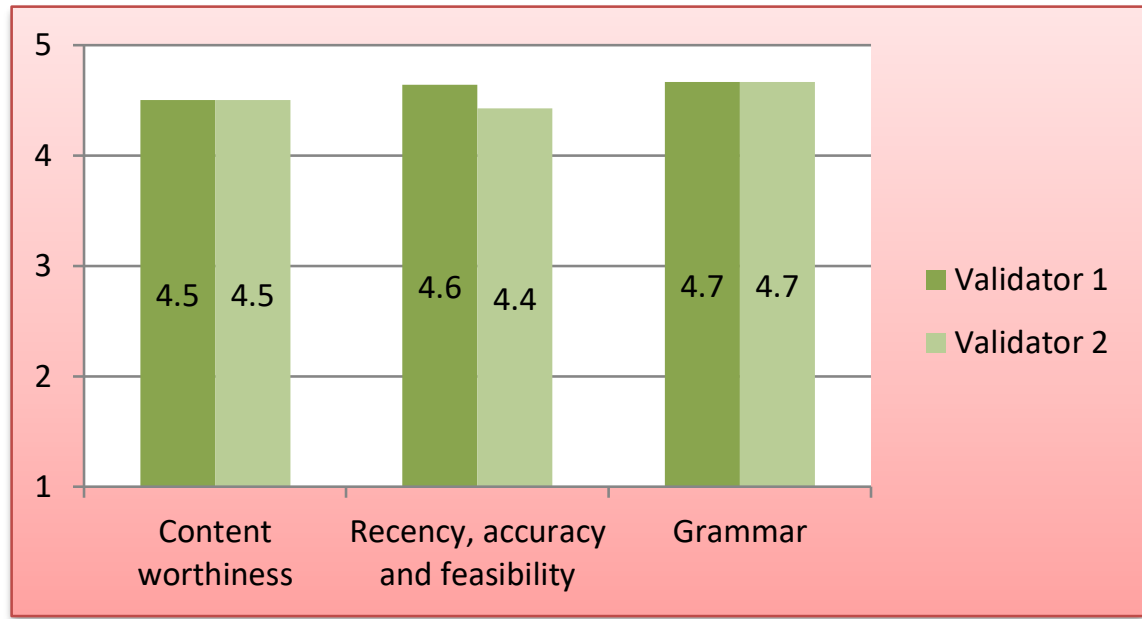

Figure 11. The Result of Material Experts' Validation

The results of the media experts' validation on the aspects of the general design and the design of the media content obtained an average of 4.9 within the highly feasible category. The following is the result of media experts' validation:

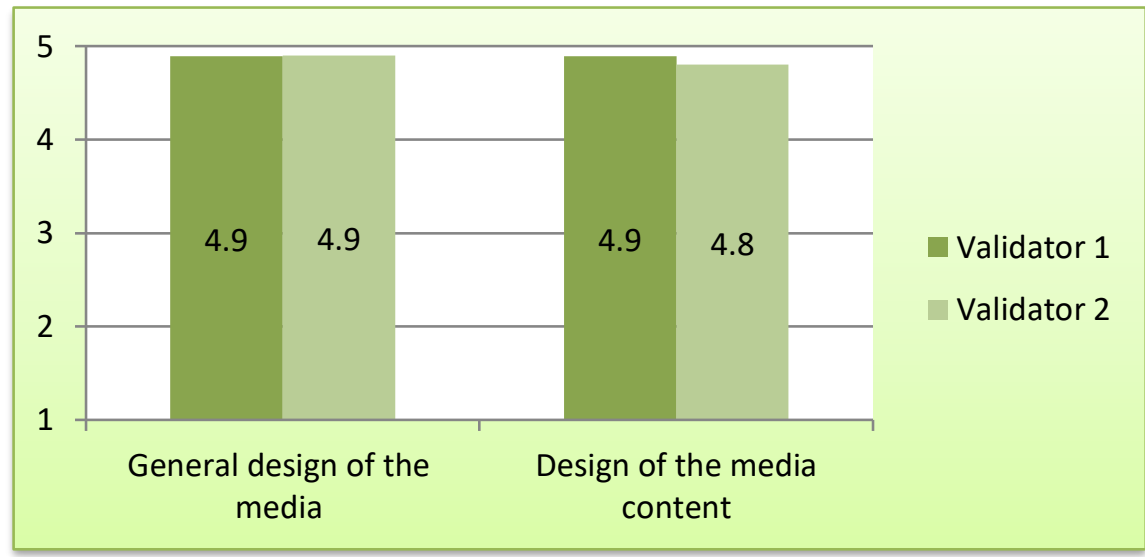

Figure 12. The Result of Media Experts' Validation

The fifth stage was the design revision. The validation generated comments and suggestions from media experts and material experts. The comments and suggestions were used as references to improve the learning media. The comments, suggestions, and revisions are summarized in Table 4.

Table 4. The Comments, Suggestions, and Revisions

\begin{tabular}{|c|c|c|}
\hline No & Comments and Suggestions & Revision/Follow Up \\
\hline 1 & The video button did not work & Repaired the video button \\
\hline 2 & $\begin{array}{l}\text { The sixth question on the evaluation was } \\
\text { ambiguous }\end{array}$ & Revised the question \\
\hline 3 & The front view was unattractive & $\begin{array}{l}\text { Improved the front view and added animation to the } \\
\text { learning media titles }\end{array}$ \\
\hline 4 & The initial display took too long & Added the SKIP button to skip the initial display \\
\hline 5 & $\begin{array}{l}\text { If you answer the question by clicking } \\
\text { on the option, then the next question } \\
\text { should be displayed }\end{array}$ & $\begin{array}{l}\text { There was no revision because a navigation button had } \\
\text { been provided }\end{array}$ \\
\hline
\end{tabular}

The sixth stage was product trials. At this stage, the improved product based on the input and advice from media and material experts had been tested to find out the students' responses on the attractiveness and effectiveness of the developed learning multimedia. The field trials 
were conducted on 50 students at Muhammadiyah Prambanan Vocational School. After they have tried the developed multimedia, they were asked to fill out questionnaires to determine their responses. The questionnaire results showed that the developed multimedia was in a very interesting category with a percentage of $89 \%$.

After conducting the field trials, the next step was effectiveness testing done by comparing the pretest and posttest during the field trials. The improvement found before and after using the developed multimedia learning was calculated using the $\mathrm{N}$-gain formula. There was a high increase in the learning outcomes with the N-Gain score of 0.8 . The following are the students' mathematics learning outcomes improvement:

Table 5. The Improvement of Students' Learning Outcomes

\begin{tabular}{lccc}
\hline & Pretest & Posttest & N-Gain Score \\
\hline Minimum Score & 60 & 87 & \\
Maximum Score & 90 & 99 & 0,8 \\
Average score & 75 & 95 & \\
\hline
\end{tabular}

The seventh stage was product revision. Based on the field trials, if the students state that the product is interesting, it can be said that the final product has been developed. If the product is not perfect, the results of the field trials will be used as the improvement references so that the final product can be obtained.

Based on the research and development results, it can be concluded that bilingual learning multimedia on the integral application material was feasible, interesting, and effective. The first step taken in developing the product was data collection such as syllabus, lesson plans, books, and other sources. After the data had been collected, the next step was to design the learning media. The designed product was then validated by material experts and media experts. The media that has been validated was revised based on the inputs from the validators. The revised product was then tried-out at the school. The data obtained at the trial stage was used to determine the attractiveness and effectiveness of the developed product. After all of the stages had been completed, the teaching material in the form of mathematics learning multimedia on integral application material to be used in mathematics learning activities was produced. Therefore, it is hoped that the existence of this learning media can help students to increase their motivation and interest, and understanding. Research by (Fadila et al., 2019; Nelwati et al., 2019; Setiyani et al., 2020; Susilawati et al., 2018; Zainil et al., 2018) has developed learning media with different variations for the development of the teaching and learning process. Therefore, development and innovation in learning are needed to make it easier for students to understand the material to be delivered.

\section{CONCLUSIONS}

Developed multimedia is feasible to use. The feasibility was seen from the results of media and material expert validation. Based on the field trials, the developed multimedia was in a very attractive category. The developed multimedia was able to improve students' learning outcomes in the high category.

It is suggested to use the developed product as an alternative media in learning mathematics so that the learning process can be more fun. The produced multimedia can be used as new reference material in the form of learning media to support education and quality in schools. For the next researchers, it is recommended to develop more interesting media, especially in mathematics. 


\section{AUTHOR CONTRIBUTIONS STATEMENT}

In writing this development article, it was conceptualized by AR as well as the methodology and writing of the original draft. for data curation and validation is done by SH. IN participates in visualization and editing.

\section{REFERENCES}

Diani, R., Hartati, N. S., \& Email, C. A. (2018). Flipbook berbasis literasi Islam: Pengembangan media pembelajaran fisika dengan 3D pageflip professional. Jurnal Inovasi Pendidikan IPA, 4(2), 234-244.

Fadila, A., Dasari, R., Setiyaningsih, S., Septiana, R., Sari, R. M., \& Rosyid, A. (2019). the development of electronic flash worksheet based on adobe flash cs6 on fraction numbers in the seventh grade of junior high school. Journal of Physics: Conference Series, $1155(1)$.

Gündüz, H. B. (2010). Digital divide in Turkish Primary Schools: Sakarya sample. Turkish Online Journal of Educational Technology, 9(1), 43-53.

Hake, R. R. (1998). Interactive-engagement versus traditional methods: A six-thousand-student survey of mechanics tests data for introductory physics courses. American Journal of Physics, 66(1), 64-74.

Hardiyantari, O. (2017). Pengembangan multimedia pembelajaran interaktif menggunakan teknik dinamis pada mata pelajaran produktif teknik komputer dan jaringan untuk sisiwa kelas X. Jurnal Inovasi Teknologi Pendidikan, 4(1), 77-83.

Kesumayanti, N., \& Putra, R. W. Y. (2017). Pengembangan bahan ajar materi persamaan kuadrat berbantuan rumus cepat. JES-MAT(Jurnal Edukasi Dan Sains Matematika), 3(2), $125-138$.

Leow, F. T., \& Neo, M. (2014). Interactive multimedia learning: Innovating classroom education in a Malaysian university. Turkish Online Journal of Educational Technology, 13(2), 99-110.

Mabruri, H., Ahmadi, F., \& Suminar, T. (2019). The development of science mobile learning media to improve primary students learning achievements. Journal of Primary Education, $8(56), 108-116$.

Made Rajendra, I., \& Made Sudana, I. (2018). The influence of interactive multimedia technology to enhance achievement students on practice skills in mechanical technology. Journal of Physics: Conference Series, 953(1-5).

Margana, \& Sukarno. (2011). Pengembangan model pembelajaran bilingual di sekolah menengah kejuruan. Jurnal Kependidikan: Penelitian Inovasi Pembelajaran. 41(1), 7993.

Merliana, N. P. E., Tantri, N. N., Evie, \& Winawati. (2019). Peranan teknologi dalam peningkatan mutu. Jurnal Penjaminan Mutu, 5(2), 214-225. 
Muchlas. (2018). Developing an online learning media using smartphone for the electrical machinery course. Turkish Online Journal of Educational Technology - TOJET, 17(1), $62-68$.

Mukhni, M., Mirna, M., \& Khairani, K. (2020). Teachers' perception of media tools in mathematics learning at senior high school. Journal of Physics: Conference Series, 1554(1-5).

Nelwati, S., Sepriyanti, N., Susanto, A., Melinda, M. S., \& Afriadi, J. (2019). The development of islamic learning media using macromedia flash on geometry. Journal of Physics: Conference Series, 1317(1).

Neo, M., Neo, T. K., \& Yap, W. L. (2008). Students' perceptions of interactive multimedia mediated web-based learning: A Malaysian perspective. ASCILITE 2008 - The Australasian Society for Computers in Learning in Tertiary Education, 1995, 658-666.

OECD. (2018). What 15-year-old students in Indonesia know and can do. Programme for International Student Assessment (PISA) Result from PISA 2018, 1-10.

Otoluwa, Y., Eraku, S., \& Yusuf, D. (2020). Pengembangan media pembelajaran berbasis lectora inspire yang diintegrasikan dengan camtasia studio pada mata pelajaran geografi materi sistem informasi geografi. Jambura Geo Education Journal, 1(1), 01-08.

Purwanti, R. D., Pratiwi, D. D., \& Rinaldi, A. (2016). Pengaruh pembelajaran berbantuan GeoGebra terhadap pemahaman konsep matematis ditinjau dari gaya kognitif. Al-Jabar: Jurnal Pendidikan Matematika, 7(1), 115-122.

Reimers, S., \& Stewart, N. (2007). Adobe flash as a medium for online experimentation: A test of reaction time measurement capabilities. Behavior Research Methods, 39(3), 365-370.

Rizki, F., Gunawan, I., \& Amirudin. (2020). The development of problem solving-based interactive learning media using lectora inspire berbasis problem solving menggunakan lectora. Indonesian Journal of Science and Mathematics Education. 03(1), 79-86.

Rusman, Kurniawan, D., \& Riyana, C. (2011). Pembelajaran berbasis teknologi informasi dan komunikasi-mengembangkan profesionalisme guru. Bandung: Rajawali Pers.

Saputri, A., Sukirno, S., Kurniawan, H., \& Probowasito, T. (2020). Developing Android gamebased learning media "go accounting" in accounting learning. Indonesian Journal on Learning and Advanced Education (IJOLAE), 2(2), 91-99.

Sarac, H. (2017). Effect of multimedia assisted 7e learning model applications on academic achievement and retention in students. European Journal of Educational Research, 6(3), 299-311.

Sari, A. S., \& Wati, I. W. K. (2020). Visibility of learning media of a culinary-based electronic magazine in blended learning. Jurnal Pendidikan Teknologi Dan Kejuruan, 26(1), 3542 .

Setiyani, Putri, D. P., Ferdianto, F., \& Fauji, S. H. (2020). Designing a digital teaching module based on mathematical communication in relation and function. Journal on Mathematics Education, 11(2), 223-236. 
Setyowati, F., \& Mintohari. (2020). Pengembangan media miniatur kereta api pada materi sistem peredaran darah manusia pembelajaran IPA SD kelas V. Jurnal Pendidikan Guru Sekolah Dasar, 8(1), 100-110.

Sholihah, D. A., \& Mahmudi, A. (2015). Keefektifan experiential learning pembelajaran matematika MTS materi bangun ruang sisi datar. Jurnal Riset Pendidikan Matematika, 2(2), 175-185.

Sugiyono. (2013). Metode penelitian pendidikan (pendekatan kuantitatif, kualitatif, dan R\&D) (16th ed.). Bandung: Alfabeta.

Supandi, M., \& Senam, S. (2020). Development of science learning media-based local wisdom Batui to improve critical thinking ability. Jurnal Pendidikan Dan Pengajaran, 52(3), 163 171.

Susilawati, W., Maryono, I., \& Maimunah, S. (2018). The development of adobe flash-based interactive multimedia to enhance students' mathematical communication skills. IOP Conference Series: Materials Science and Engineering, 434(1).

Syamarro, N., Winarso, W., \& Saluky, S. (2015). Pengaruh motivasi dan persepsi siswa pada matematika terhadap prestasi belajar matematika siswa kelas VIII di MTS Al-Hidayah Dukupuntang kabupaten Cirebon (pokok bahasan kubus dan balok). Eduma: Mathematics Education Learning and Teaching, 4(2), 105-111.

Triyanto, E., Anitah, S., \& Suryani, N. (2013). Peran kepemimpinan kepala sekolah dalam pemanfaatan media pembelajaran sebagai upaya peningkatan kualitas proses pembelajaran. Jurnal Teknologi Pendidikan, 1(2), 226-238.

Ulpah, M., \& Novikasari, I. (2020). Developing islamic context-based learning materials in increasing students' mathematical understanding. Al-Jabar: Jurnal Pendidikan Matematika, 11(2), 29-38.

Wahyuni, D., Masykur, R., \& Pratiwi, D. D. (2019). Pengembangan multimedia pembelajaran matematika dengan pendekatan matematika realistik. Jurnal Program Studi Pendidikan Matematika, 8(1), 32-40.

Widyastuti, W., Wijaya, A. P., Rumite, W., \& Marpaung, R. R. T. (2018). Minat siswa terhadap matematika dan hubungannya dengan metode pembelajaran dan efikasi diri. Jurnal Pendidikan Matematika, 13(1), 83-100.

Zainil, M., Prahmana, R. C. I., Helsa, Y., \& Hendri, S. (2018). ICT media design for higher grade of elementary school mathematics learning using CS6 program. Journal of Physics: Conference Series, 943(1), 0-6.

Zengin, Y. (2017). International forum of educational technology \& society investigating the use of the Khan Academy and mathematics software with a flipped classroom approach in mathematics teaching published by: International forum of educational technology \& society inv. Journal of Educational Technoloy \& Society, 20(2), 89-100. 